\title{
Seasonal depth distribution and thermal experience of the non-indigenous round goby Neogobius melanostomus in the Baltic Sea: implications to key trophic relations
}

\author{
Jane W. Behrens $(\mathbb{D} \cdot$ Marie P. Ryberg $(\mathbb{D} \cdot$ Heli Einberg $(\mathbb{D} \cdot$ Redik Eschbaum $(\mathbb{D} \cdot$ \\ Ann-Britt Florin (1) - Wlodzimierz Grygiel (1) - Jens Peter Herrmann • \\ Bastian Huwer (1) - Karin Hüssy (1) - Elina Knospina • Kristiina Nõomaa (1)

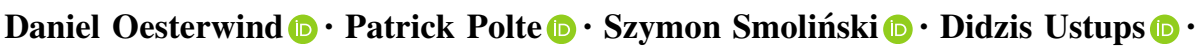 \\ Mikael van Deurs $(\mathbb{D} \cdot$ Henn Ojaveer $\mathbb{D}$
}

Received: 25 January 2021 / Accepted: 5 October 2021/Published online: 5 November 2021

(C) The Author(s) 2021

\begin{abstract}
Native to the Ponto-Caspian region, the benthic round goby (Neogobius melanostomus) has invaded several European inland waterbodies as well as the North American Great Lakes and the Baltic Sea. The species is capable of reaching very high densities in the invaded ecosystems, with not only evidence for significant food-web effects on the native biota and habitats, but also negative implications to coastal fishers. Although generally considered a coastal
\end{abstract}

Supplementary Information The online version contains supplementary material available at https://doi.org/10.1007/ s10530-021-02662-w.

J. W. Behrens $(\bowtie) \cdot$ M. P. Ryberg .

B. Huwer · K. Hüssy · M. van Deurs · H. Ojaveer National Institute of Aquatic Resources, Technical University of Denmark, Kemitorvet, Building 202, 2800 Kgs. Lyngby, Denmark

e-mail: jabeh@aqua.dtu.dk

\section{H. Einberg $\cdot$ R. Eschbaum $\cdot$ K. Nõomaa}

Estonian Marine Institute, University of Tartu, Mäealuse 14, 12618 Tallinn, Estonia

\section{A.-B. Florin}

Department of Aquatic Resources, Institute of Coastal Research, Swedish University of Agricultural Sciences, Skolgatan 6, 74242 Öregrund, Sweden

W. Grygiel · S. Smoliński

Department of Fisheries Resources, National Marine Fisheries Research Institute, Kołłątaja 1, 81-332 Gdynia, Poland species, it has been shown that round goby migrate to deeper areas of the Great Lakes and other inland lakes during the cold season. Such seasonal movements may create new spatio-temporal ecosystem consequences in invaded systems. To seek evidence for seasonal depth distribution in coastal marine habitats, we compiled all available catch data for round goby in the Baltic Sea since its invasion and until 2017. We furthermore related the depths at capture for each season with the ambient thermal environment. The round goby spend autumn and winter at significantly deeper and offshore areas

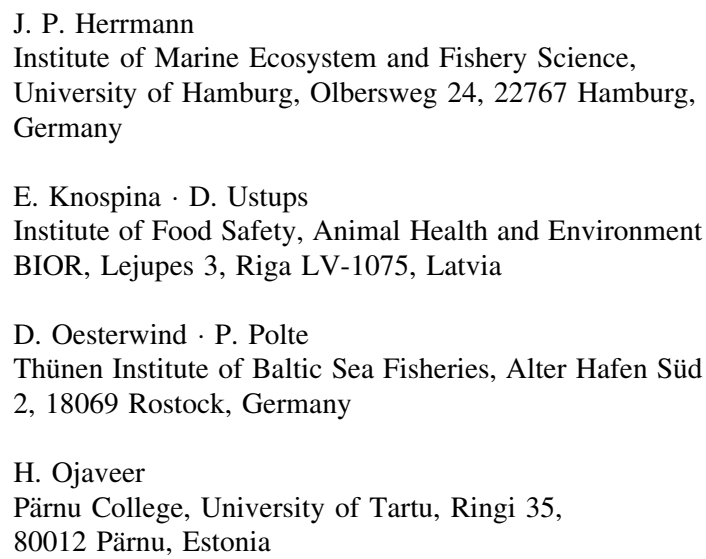


compared to spring and summer months; few fish were captured at depths $<25 \mathrm{~m}$ in these colder months. Similarly, in spring and summer, round goby were not captured at depths $>25 \mathrm{~m}$. The thermal conditions at which round goby were caught varied significantly between seasons, being on average $18.3^{\circ} \mathrm{C}$ during summer, and dropping to a low $3.8{ }^{\circ} \mathrm{C}$ during winter months. Overall, the fish sought the depths within each season with the highest possible temperatures. The spatial distribution of the round goby substantially overlaps with that of its main and preferred prey (mussels) and with that of its competitor for food (flatfish), but only moderately with the coastal predatory fish (perch), indicating thereby very complex trophic interactions associated with this invasion. Further investigations should aim at quantifying the food web consequences and coupling effects between different habitats related to seasonal migrations of the round goby, both in terms of the species as a competitor, predator and prey.

Keywords Depth - Invasive species · Migration · Predator $\cdot$ Prey $\cdot$ Temperature

\section{Introduction}

Migration is a common phenomenon within many taxa of animals, terrestrial as well as aquatic. One way to define migration is as a synchronized, large-distance movement of a population between separate habitats, which usually occurs with a regular periodicity (Leggett 1977; Dingle and Drake 2007; Lucas and Baras 2001). Such spatial displacement, often of substantial biomasses may exert significant impact on community structure and function, flux of energy and nutrients between different areas and habitats, and on species interactions (Deegan 1993; Varpe et al 2005; Marczak et al 2007; Bauer and Hoye 2014; van Deurs et al 2016). Not surprisingly, migration has received substantial attention by scientist for decades. This includes not only describing and characterizing the observed patterns and their implications for trophic interactions, but also relating the spatial displacement to causal drivers, e.g. seasonal changes in habitatspecific trade-offs between predation risk and growth rate, spawning, or avoidance of unfavorable or seeking of preferred environmental conditions (Brodersen et al
2008; Kanciruk and Hernkinn 1978; Quinn and Dittman 1990, O`Driscoll 2004, Sigler and Csepp 2007).

In some cases, actively migrating mobile nonnative taxa are of concern due to their ability to colonize new areas and pose threat to native species. Examples of these are the Chinese mitten crab Eriocheir sinensis, the snow crab Chionoecetes opilio, the lionfish Pterois spp. and the round goby Neogobius melanostomus (Herborg et al 2003; Nichol \& Somerton 2015; Tamburello \& Côté 2015; Kornis et al 2012). Round goby is invasive on both sides of the Atlantic Ocean by occurring in high numbers in the North American Great Lakes, the Baltic Sea and several European inland waterbodies (Kornis et al. 2012). Because of large areas colonized and high population sizes achieved, major effects on the native species and communities have been documented in the wake of its invasion (Crane and Einhouse 2015; Karlson et al. 2007; Bergstrom and Mesinger 2009; Poos et al. 2010; French and Jude 2001). Recent investigations in the Great Lakes and other inland lakes of North America show that in these environments, this species engages in annual nearshore/ offshore migrations, typically of the entire populations, and that this seasonal migration of the round goby displaces a large biomass, with substantial ecological impacts (Andres et al. 2020, Pennuto et al. 2021). In general, the round goby has a generalist feeding strategy and preys upon a wide range of different pelagic and benthic invertebrates (Skabeikis and Lesutiene 2015; Nurkse et al. 2016) and also fish eggs and small fish (Schrandt et al. 2016; Wiegleb et al. 2019). Through direct predation the round goby has likely caused a major decline of dominant benthic macroinvertebrates (and mussels in particular) in shallow areas in the Baltic Sea (Skabeikis et al. 2019). The round goby has also become an important competitor with native benthic feeding fish (e.g. flounder Platichthys flesus) over macroinvertebrate prey (Karlson et al. 2007; Lederer et al. 2008; Skabeikis et al. 2019). To be able to evaluate the impact a non-native invasive species has on the invaded system, it is thus imperative to understand the species ecology, including migration patterns, for planning of any mitigation measures (Ojaveer et al., 2015).

With a temperate climate, the Baltic Sea provides a seasonally strongly variable habitat for the round 
goby, with water temperatures on average varying between 17 and $18{ }^{\circ} \mathrm{C}$ in summer, dropping to around zero in winter. The seasonal changes in temperature are superimposed by the typically two-layer salinity stratification. Cold water bodies, formed during winter, persist long into the summer season below the halocline, whereas a summer seasonal thermocline develops above the halocline in the surface waters at depths of about $15-20 \mathrm{~m}$. Therefore, the range of the surface temperature variation may be as large as $25^{\circ} \mathrm{C}$, while within the deeper water layers, e.g. of the Gotland Deep, is on average only $5{ }^{\circ} \mathrm{C}$ (range $3-8{ }^{\circ} \mathrm{C}$ ) (BACC 2015).

In this study, we used catch data from 1994 to 2017 to investigate pan-Baltic seasonal depth distributions of the round goby, and correlated this with the thermal environment at the place of capture. We hypothesize that (1) there is a seasonal pattern in depth distribution of round goby, and (2) the seasonal pattern in depth distributions of round goby relates to avoidance of cold-water temperatures in shallow waters during the cold period of the year. In addition, we compared how round goby depth distribution overlaps with the preferred major macrozoobenthic prey (the blue mussel Mytilus edulis), a major competitor for food (flounder Platichthys spp.) and an important piscivorous predator in coastal areas (perch Perca fluviatilis).

\section{Materials and methods}

Data

Data represents a compilation of altogether 1084 panBaltic catches of round goby from 1994 to 2017. All available data were used, although data were not available for all years in all areas (Table 1 and Fig. 1). Individual catches of round goby were allocated to one of four quarters (Q); Q1 (January-March), Q2 (AprilJune); Q3 (July-September) or Q4 (October-December). Information on depth and gear type was available for each catch, except for 12 catches $(1.1 \%)$, where information on bottom depth was extracted from the ETOPO1 Global Relief Model that includes Baltic Sea Bathymetry by using the function "getNOAA.bathy" at resolution of $1 \mathrm{~min}$ from the $\mathrm{R}$ package marmap (Amante and Eakins 2003; R Core Team 2016; Pante et al. 2017). Information about the bottom water temperature at the catch locations (i.e. temperatures experienced by the caught goby) was obtained for 801 of the 1084 catches (74\%). To evaluate depth-specific thermal experience of round goby at the remaining locations, we extracted all available bottom water temperature measurements from 1994 to 2017, for the area between 53 and $60^{\circ} \mathrm{N}$ and $08-30^{\circ} \mathrm{E}$, from the ICES hydrographic database (ICES Dataset on Ocean Hydrography, The International Council for the Exploration of the Sea, Copenhagen 2017) and calculated the average bottom temperature for each quarter and $5 \mathrm{~m}$ depth intervals. These data were only used for visual interpretation of the relationship between bottom temperature and total number of fish summed at $5 \mathrm{~m}$ depth interval. Comparison of the bottom temperature profiles of the western and eastern part, as well as the southern and northern part of the region revealed a highly comparable pattern, thus a single depth profile for the whole region was used. The total number of round gobies from one catch divided by mean of observations from each gear type is here defined as standardized Catch Per Unit Effort (stand CPUE).

\section{Statistical analysis}

We tested the following two hypotheses (1) there is a seasonal pattern in depth distribution of round goby, and (2) the seasonal pattern in depth distributions of round goby relates to avoidance of cold-water temperatures in shallow waters during the cold period of the year. A post hoc analysis (Kruskal-Wallis and Dunn's Multiple Comparison test) was performed to statistically test hypothesis 1 (i.e. to examine whether depth of catches changed significantly between quarters) (R Core Team 2016). A linear mixed intercept model was used to statistically test the second hypothesis. The linear mixed-effects model (LME) from the NLME package in $\mathrm{R}$ was used for modelling (Pinheiro et al. 2016; R Core Team 2016). For reduction of the fixed structure, we used maximum likelihood (ML) estimation procedure and a backward selection routine based on manual calculations of Log Lik values for each of the variables in the model. The Akaike's Information Criterion (AIC; Burnham and Anderson 1998) was used in model comparison. Restricted maximum likelihood (REML) estimation procedure of the final model was used for better estimation of the random variance comparing to ML estimation (Zuur et al. 2009). Model validation was 


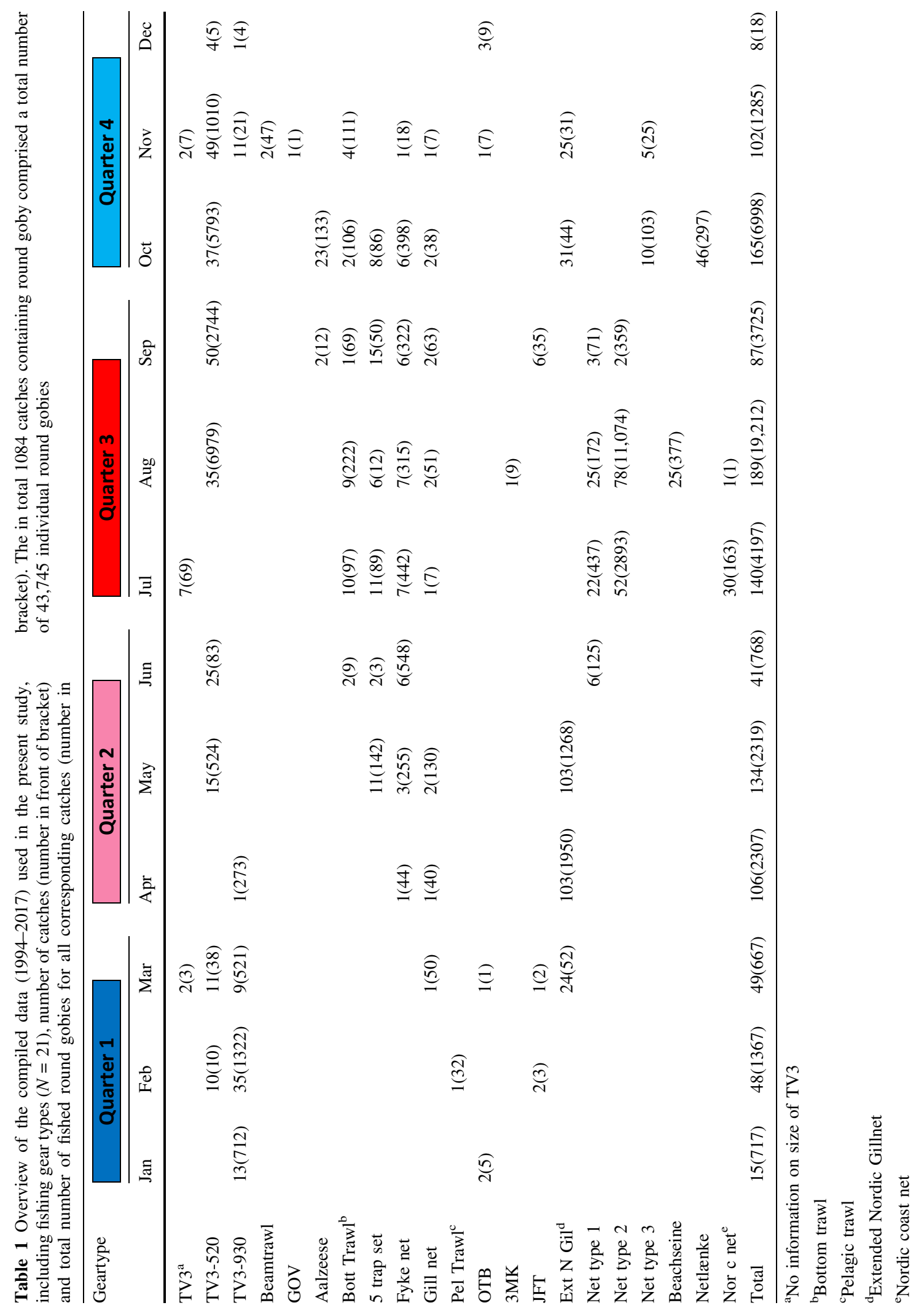




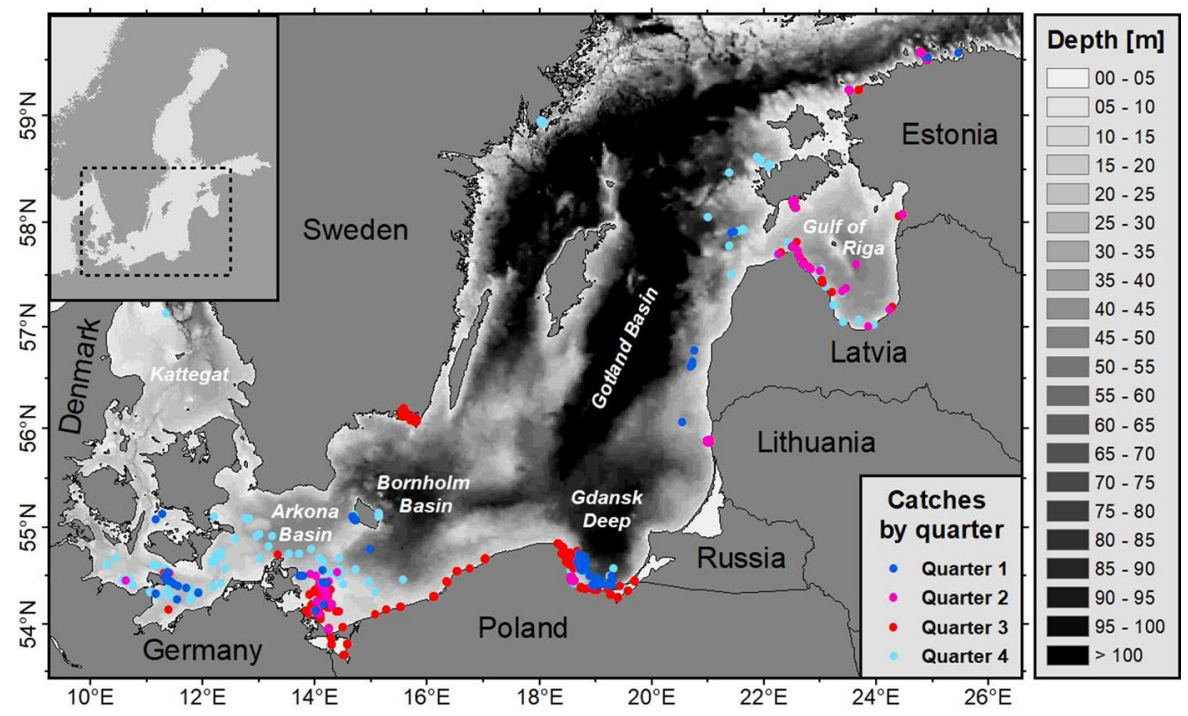

Fig. 1 Positions of catches containing round goby in the period 1994-2017 by quarter. Quarter 1 (dark blue) is January-March, quarter 2 (pink) is April-June, quarter 3 (red) is July-September

done by checking the assumptions of normality and independence of residuals.

The linear mixed intercept model included a $\log$ transformation of the response variable, stand CPUE. Due to high variance in observations of round goby between gear types (Fig. S1 A and B), we allowed the within-gear type errors (residuals) to vary between gear types by using varIdent variance structure in the model. Because observations from 8 of the 21 gear types had incomplete information on temperature, the linear mixed model only contained 13 types of gear. The full model for examination of whether water temperature drives the depth distribution of round goby included a fixed effect of the observed temperature for each catch and a factor named quarter with 4 levels (i.e. Q1-Q4) to account for differences in standardized CPUE over the year and gear type (13 levels) as random effect to capture systematic deviations in the standardized CPUE for different gear types:

(Temperature) model) $\log (\operatorname{stand} C P U E)_{i}=\mu+$ $\alpha\left(\right.$ quarter $\left._{i}\right)+\beta *$ temperature $_{i}+\gamma\left(\right.$ geartype $\left._{i}\right)+$ $\varepsilon_{i} i=801$

(Model assumptions) $\varepsilon_{i} \sim$ i.i.d.N $\left(0, \sigma_{\text {geartype }_{i}}^{2}\right)$, $\gamma\left(\right.$ geartype $\left._{i}\right) \sim$ i.i.d. $\mathrm{N}\left(0, \sigma_{\gamma}^{2}\right)$

To test the robustness of the post hoc analysis as stated above we performed the same test on a subset of and quarter 4 (light blue) is October-December. In total, 1084 catches contained round goby, comprising a total number of 43,745 individual round gobies

data (i.e. gear type $=$ TV3-520, $\mathrm{N}$ catches $=236$ ) . Only data from the same gear type and with data from all four quarters were used in the analysis. Missing information of temperature on all catches from gear type TV3-520 made it impossible to test the second hypothesis.

Calculation of spatial overlap between the round goby and trophically associated species

Overlap of the distribution area of the round goby and trophically-associated species was measured as a percentage of the distribution area of blue mussel, perch and flounder where the round goby was present. The overlap was calculated for three quarters (Q2-Q4; i.e. spring, summer and autumn), when trophic interactions with involvement of fish generally occur in the Baltic Sea. Map analysis was carried out with ArcMap (ArcGIS 10.6) tool Raster Calculation, under Spatial Analyst Tools-Map Algebra (https://desktop. arcgis.com/en/arcmap/10.3/tools/spatial-analysttoolbox/raster-calculator.htm).

First, new raster layers were made for the round goby and the three trophically associated species, blue mussel, flounder and perch by applying conditional tool "Con" with binominal values ( 0 and 1$)$ : 0 — where a given taxon was not present, 1-a given taxon was present. Potential round goby habitats were divided 
into quarters (Q2-Q4), which all correspond to the depth ranges describing the interquartile areas in Fig. 2a.

Secondly, raster calculation subtraction between rasters was used (e.g. raster "M. edulis" - raster "round goby Q2"). New output rasters had two values 0 and 1 , where 0 presented overlap between layers of a trophically associated species and the round goby, and 1 presented the area, where a trophically associated species was present but round goby was not. To calculate the overlap percentage between a trophically associated species and round goby, pixel values were used.

Spatial overlap was calculated based on the formula:

Overlap percentage $=\mathrm{P} 0 * 100 \% /(\mathrm{P} 0+\mathrm{P} 1)$,

where:

$\mathrm{P} 0=$ Pixel values for the overlap area,

P1 = Pixel values for the habitat area of trophically associated species (Fig. 4E-G), where there was no overlap with potential round goby habitat.

\section{Results}

Observations and post hoc analysis

The depth at which round goby were caught varied significantly between quarters $(p<0.001)$, except for Q2 and Q3, where fish were caught in shallow water of average depths of 9.4 and $8.2 \mathrm{~m}$, respectively (Fig. 2a). Catches during autumn- and wintertime (Q4 and Q1) revealed that fish spend this period of the year at much deeper waters, especially in Q1 (January to March) where the fish on average were caught at $35.6 \mathrm{~m}$ (Fig. 2a). The maximum depth that a round goby was caught at was $90 \mathrm{~m}$ in Q4, at the northwest coast of the Estonian island Saaremaa.

The water temperature at which round goby were caught varied significantly between quarters $(p<0.001)$ except for Q2 and Q4 (Fig. 2b). Fish experienced the highest temperatures during summer (Q3) with an average of $18.3{ }^{\circ} \mathrm{C}$, which dropped to a low $3.8^{\circ} \mathrm{C}$ during January-March (Q1). In contrast, the temperatures experienced by the fish in spring/ early summer (Q2) and autumn/early winter (Q4) was highly comparable, 11.3 and $10.4{ }^{\circ} \mathrm{C}$, respectively. Thus, overall the fish experienced a span in average

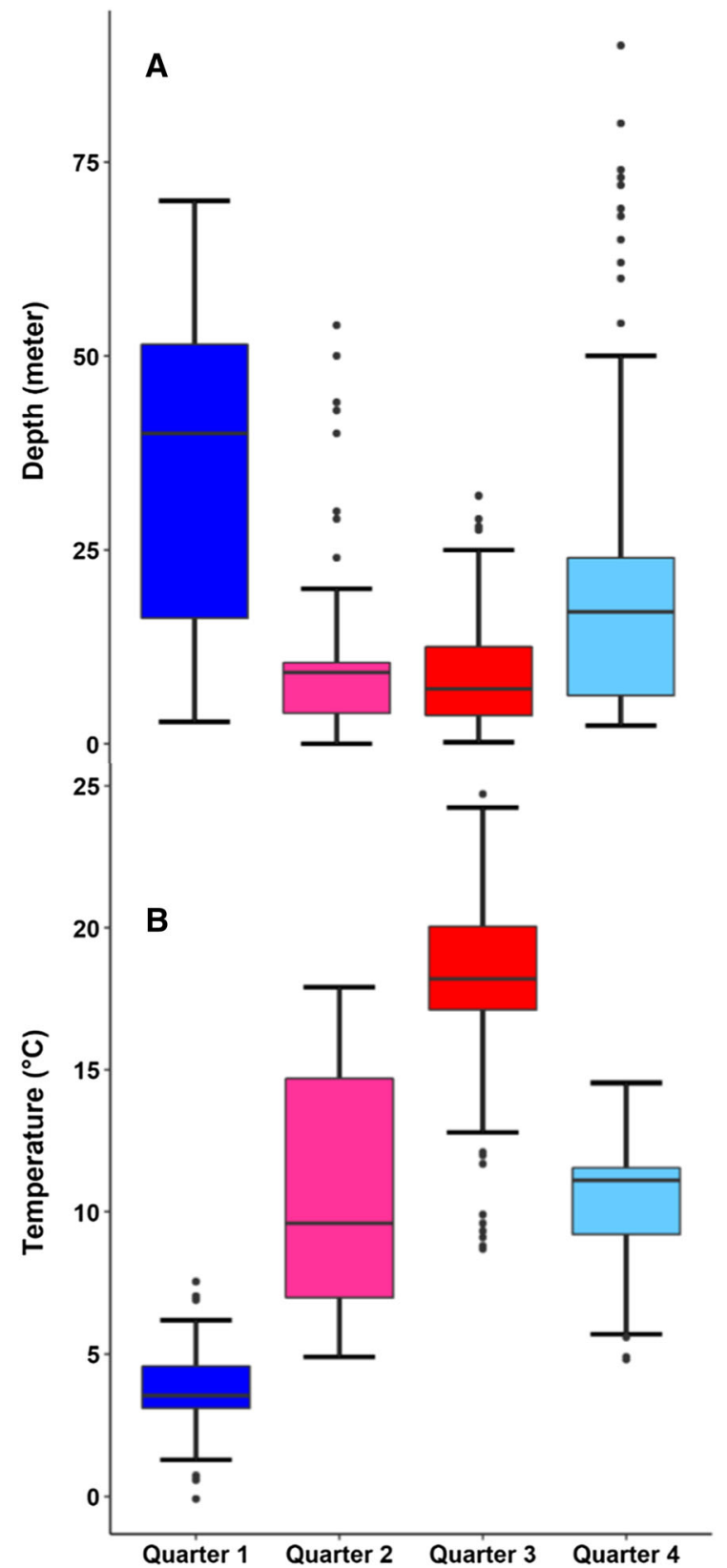

Fig. 2 Seasonal depth (a) and thermal experience (b) in relation to quarter for goby caught between 1994 and 2017. Quarter 1 is January-March, quarter 2 is April-June, quarter 3 is JulySeptember and quarter 4 is October-December. Solid line is the median, box is the interquartile area (bottom and top are 25th and 75 th percentiles, respectively). Whiskers show either the $\mathrm{max} / \mathrm{min}$ observation if within 1.5 of the interquartile range or 1.5 times the interquartile range. For details of used gear types and number of catches see Table 1

temperature of $14.5^{\circ} \mathrm{C}$ during the annual cycle. The lowest temperature where round goby was fished was 
$0.1{ }^{\circ} \mathrm{C}$ at $14 \mathrm{~m}$ depth in $\mathrm{Q} 1$, whereas the highest was $24.7^{\circ} \mathrm{C}$ at 4 m depth in Q3 (Fig. 2b).

Comparison of total number of round goby caught at each $5 \mathrm{~m}$ depth interval in each quarter (Fig. 3a) and bottom water temperature profiles extracted from the ICES database (Fig. 3b), revealed that in three out of four quarters, the depth at which the highest catch was obtained, was linked with the highest bottom water temperature. The exception was Q1, where the fish would have experienced a few degrees higher

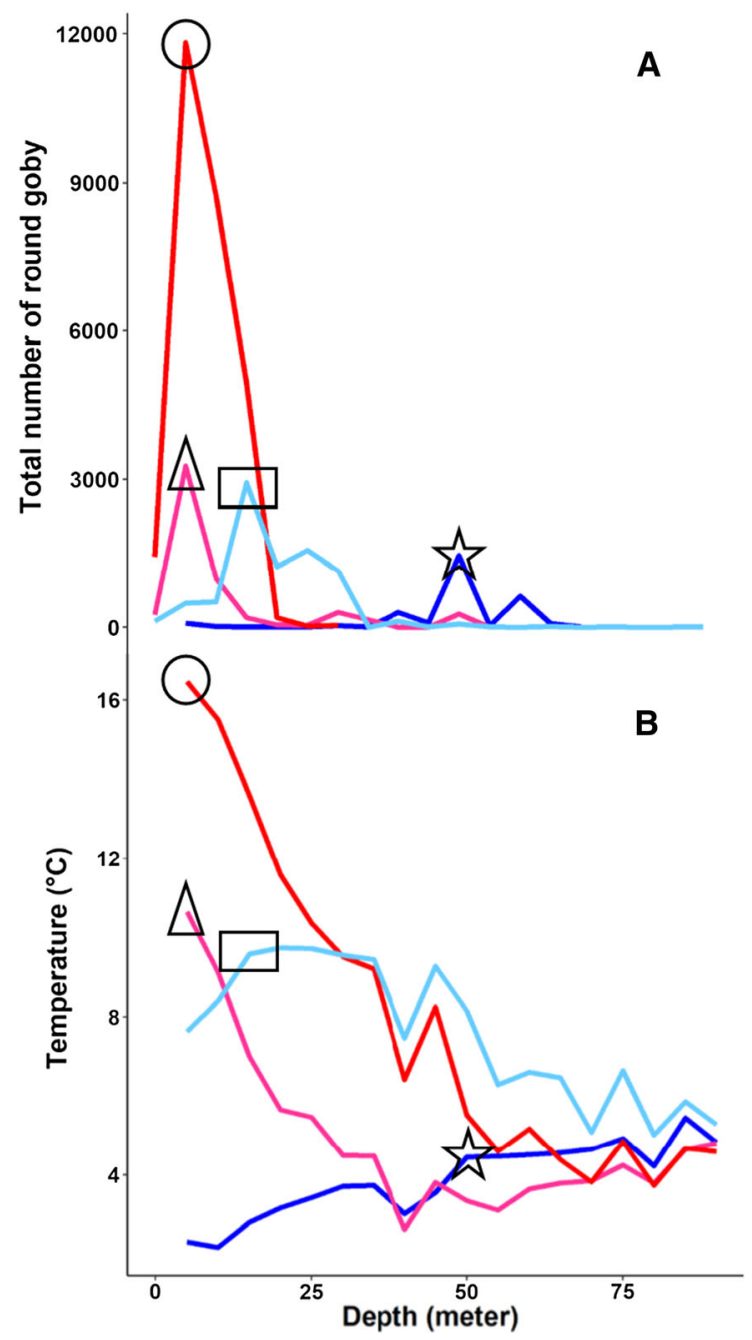

Fig. 3 a The total number of round goby caught at each $5 \mathrm{~m}$ depth interval for each quarter (dark blue: Q1; pink: Q2; red: Q3 and light blue: Q4). The four symbols indicate the peak of number of fish for each quarter (star for Q1, triangle for Q2, circle for Q3 and square for Q4). b Bottom temperatures (ICES database) in relation to depth for Q1-4. The four different symbols (see A) illustrate at what temperature number of caught round goby at a given depth was highest temperatures had they migrated $35-40 \mathrm{~m}$ deeper (i.e. to $85-90 \mathrm{~m}$ or deeper) (Fig. 3a and b).

\section{Statistical modelling}

The linear mixed intercept model confirmed our second hypothesis that seasonal depth distribution of the fish is linked to the thermal conditions: the round goby avoids cold temperatures during winter at shallow depths. The full model was not reduced as both temperature and quarter turned out to be significant (Table 2) and model reduction only increased AIC (i.e. insufficient model reduction). The effect of temperature supported our observations that round goby seem to seek areas (depths) with highest possible temperatures as the overall temperature effect turned out to be positive for stand CPUE of round goby throughout a whole year $(\alpha=0.049, p=0.002)$ (Table 2). The significance of the factor quarter revealed that mean stand CPUE differed over the year resulting in 4 different intercepts of the final model (Table 2).

\section{Test of robustness}

Depth from catches using the TV3-520 gear differed significantly in depth over the year $(p<0.001)$. Fish were caught in significantly deeper water in Q1 (27.7 $\mathrm{m})$ and Q4 (23.4 m) compared to Q2 (16.0 m) and Q3 $(14.3 \mathrm{~m})$. The water temperature at which round goby were caught with TV3-520 varied significantly between quarters $(p<0.001)$. The highest temperature fish experienced was in summer (Q3) with an average on $17.0^{\circ} \mathrm{C}$. In contrast, the coldest temperature experienced by the fish was found in winter (Q1) with an average of $2.5^{\circ} \mathrm{C}$. In Q2 and Q4, fish experienced more comparable temperatures, however still significant from each other $\left(13.0^{\circ} \mathrm{C}\right.$ and $10.5{ }^{\circ} \mathrm{C}$, respectively, $p=0.001$ ).

Spatial overlap with trophically associated species

The highest overlap between the distribution of the round goby and the three investigated trophically associated species (Fig. 4) was observed for flounder (competitor) and blue mussel (preferred prey) in autumn (70.0 and $50.1 \%$, respectively), while the lowest overlap was always observed for perch $(\leq 20 \%$; Table 3$)$, predator on round goby. 
Table 2 Summary of fixed and random effects and their associated parameters retained in the final temperature model for $\log$ (stand CPUE).

Parameter estimates by REML, their standard errors (SE), degrees of freedom (DF) and significance values $(\mathrm{P})$ are shown

\begin{tabular}{lllll}
\hline Parameter & Estimate & SE & DF & P \\
\hline Fixed effects & & & 784 & $<0.001$ \\
Quarter: & -1.897 & 0.355 & & \\
Quarter 1 & -1.040 & 0.372 & & \\
Quarter 2 & -1.453 & 0.412 & & \\
Quarter 3 & -2.207 & 0.358 & & \\
Quarter 4 & 0.049 & 0.016 & 784 & \\
Temperature & & & & 0.002 \\
Random effects (SD units) & & & & \\
Among-geartype $\left(\sigma_{\gamma}^{2}\right)$ & & & & \\
Within-geartype (residuals) $\left(\sigma_{\text {geartype }}^{2}\right)$ & & & & \\
$\mathrm{N}=801$ & & & & \\
\hline
\end{tabular}

\section{Discussion}

The present study has resolved one of the major gaps in our knowledge related to the seasonal distribution pattern of the round goby in one of its invasion hotspots-the Baltic Sea. Using all available round goby catch data in the Baltic Sea since its introduction in the early 1990s, we were able to show that the round goby stay in deeper water layers during the cold season as compared to spring and summer. This ultimately reveals a pronounced seasonal migration between shallow coastal waters and offshore areas, which can be related directly to different thermal conditions between the seasons. This finding mirrors the annual inshore/offshore seasonal migration of round goby documented in some North American lakes (Andres et al. 2020, Pennuto et al. 2021) and previously suggested in Europe (Sapota and Skora 2005; Christoffersen et al. 2019). These migration events have been shown to translocate significant amounts of energy, prey, and nutrients in a range of lake sizes (Johnson et al. 2005, Andres et al. 2020, Pennuto et al. 2021). ECThe deepest location previously recorded was $130 \mathrm{~m}$ in the North American Great Lakes (Walsh et al. 2007) (although based on much less extensive spatial data), as opposed to $90 \mathrm{~m}$ in the Baltic Sea in this study.

Potential drivers of the described migration

Migration in fish can be triggered by various drivers, like the nutritional state of the individual, food-web interactions (incl. cannibalism, predator avoidance), or environmental factors such as temperature, salinity and oxygen conditions (Kanciruk and Hernkind 1978; Brönmark et al. 2008; Bazazi et al. 2011). Many species living at temperate latitudes retreat to avoid cold exposure (Sunday et al. 2014), and maybe not surprisingly, our results reveal the same for round goby which avoids the shallow coastal waters during the coldest period where water temperatures can decrease below $0{ }^{\circ} \mathrm{C}$. Notably, our data show that round goby not only avoid the very cold shallow water during winter, but that the fish actively seeks the highest available temperature within the depth range in the different seasons. In other words, round goby selects depths that offer the highest possible temperatures for the season.

Mobile ectotherms possess the advantage of being able to actively choose a thermal environment that enables them to maintain a sufficient or even high physiological performance (Reynolds and Casterlin 1979; Sunday et al. 2014), and the observed 'thermophilic behavior' may be a relic from the species place of origin, to which their physiology is adapted. In this context, it is important to note that water temperatures are higher in their native Ponto-Caspian region (average summer temperatures of aprox. $22-28{ }^{\circ} \mathrm{C}$ ) compared to the invaded Baltic Sea (Dumont 1998; Olenin 2002; Schiewer 2008). In a recent laboratory study, Christensen et al. (2021) offered Baltic round goby a thermal range from 5 to $25^{\circ} \mathrm{C}$, and found that the fish preferred on average $21^{\circ} \mathrm{C}$. Furthermore, most fish stayed within a thermal range of 18 and $24{ }^{\circ} \mathrm{C}$, and had the highest aerobic performance between 15 and $28{ }^{\circ} \mathrm{C}$. A dislike for 

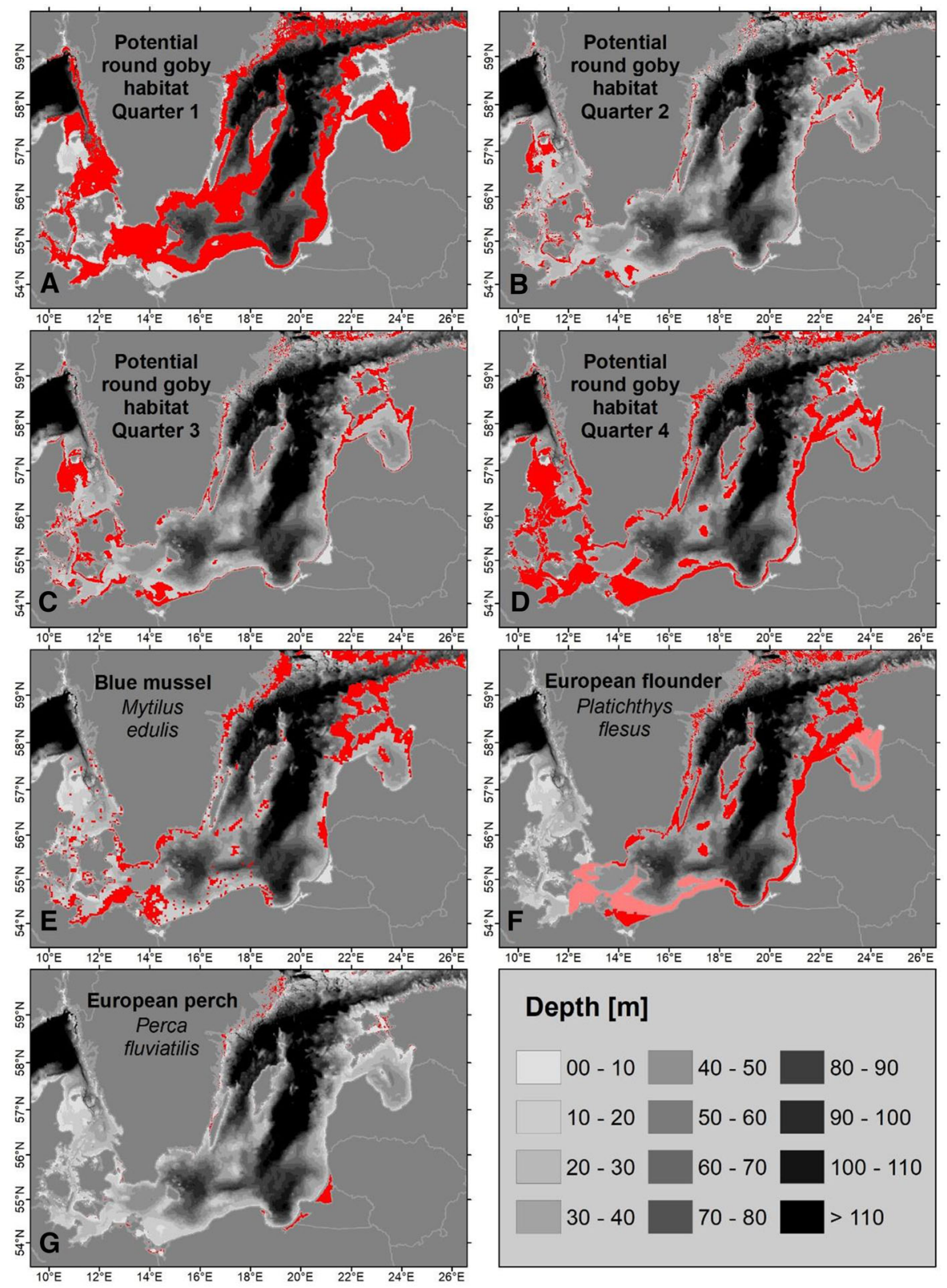

Fig. 4 Potential overlap of round goby with three Baltic key species that interact with round goby as either prey (Blue mussel), competitor for food (Baltic flounder), or predator (European perch). a-d Potential habitat of round goby in Q1, Q2, Q3 and Q4, respectively, based on the catch data in the present study. Red areas correspond to the depth ranges describing the interquartile areas in Fig. 2. e Occurrence of Blue mussel (Mytilus edulis) (red areas; data from HELCOM

cold waters may also explain why round goby, despite a pan-Baltic distribution, have only been observed in very few numbers in the northernmost (and coldest)

Map \& Data Service https://helcom.fi/baltic-sea-trends/datamaps/), f Spawning areas of Baltic flounder (Platichthys solemdali) (red areas; data obtained from HELCOM Map \& Data Service https://helcom.fi/baltic-sea-trends/data-maps/), g Recruitment areas of European perch (Perca fluviatilis) (red areas; data from HELCOM Map and Data Service https:// helcom.fi/baltic-sea-trends/data-maps/)

areas of the Baltic Sea, more specifically in Raahe in the southern part of the Bothnian Bay, but not in any adjacent or more northerly areas (Puntila et al. 2018). 
Table 3 Overlap of the distribution area of the round goby and trophically-associated species in the Baltic Sea, measured as a percentage of the distribution area of blue mussel (Mytilus edulis), perch (Perca fluviatilis) and flounder (Platichthys flesus) where the round goby was present

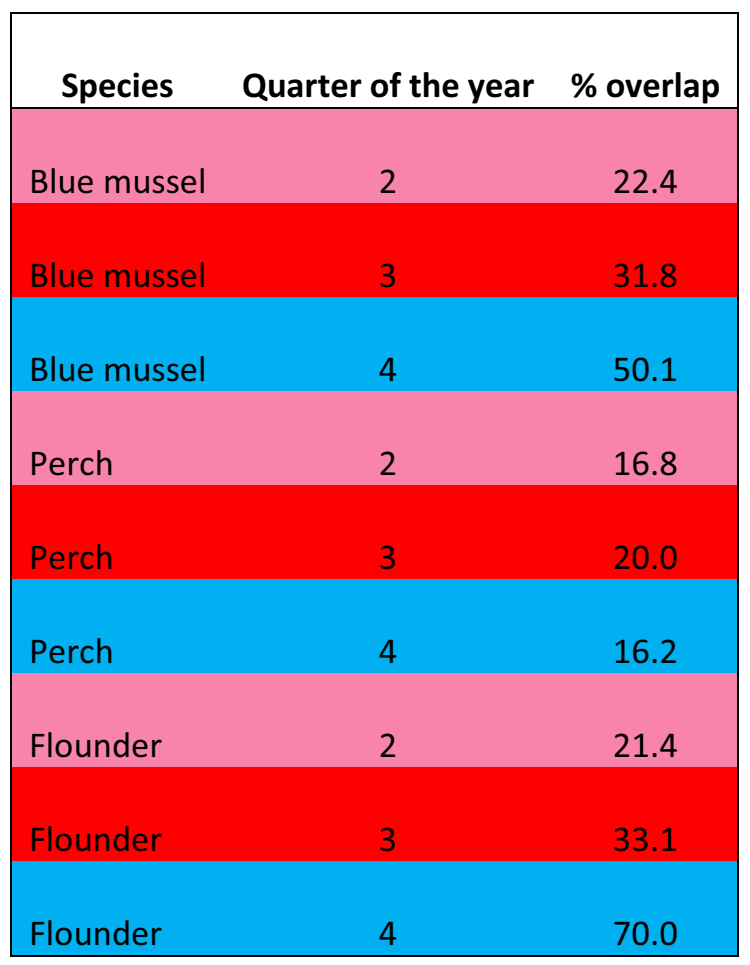

In addition, being in shallow (warmer) waters during spring and summer offers good living conditions related to the high availability of preferred prey (e.g. bivalves and arthropods), spawning opportunities, and favoured hard-bottom substrates (Sapota, 2004).

The ecological implications of biomass movement: round goby as a predator

Our depth distribution maps show that annually, blue mussels and round goby co-occur in over $70 \%$ of the of the habit available to both species (Fig. 4), and further calculations (based on the presence of the round goby in the distribution area of blue mussels) suggest the highest impact risk of round goby in autumn (Q4). Irrespectively of their size, round goby prefers the smaller blue mussels (Schwartzbach et al. 2019), and there is evidence that they feed efficiently on newly settled mollusks, causing a severe constraint for blue mussel recovery (Skabeikis et al. 2018). Mussels are important ecosystem engineers, that provide habitat for a diverse fauna and flora, and they furthermore mitigate eutrophication effects thorough filtration (Donadi et al. 2015; Chowdhury et al. 2016; Petersen et al. 2016). A substantial removal of mussels will likely affect the whole ecosystem functioning in the affected (mostly near-coastal shallow) areas.

Round goby caught in winter in the NE Baltic Sea with stomachs containing the soft-shelled clam Limecola balthica (Linnaeus, 1758) (K. Nõomaa, unpubl. data), suggest that they also feed during the winter. Considering that the fish does spend an extended period in deeper waters, some impact may be expected, and the nature of the impact and its' magnitude should be further investigated.

The ecological implications of biomass movement: round goby as a competitor

Resource competition (such as for prey, habitat and space) is an important factor for shaping biotic communities in aquatic ecosystems. There are several examples of competitive superiority of the round goby leading to outcompeting of native fish in invaded freshwater habitats (e.g. Balshine et al. 2005; Bergstrom and Mensinger 2009). Food competition with native fishes also occurs in the Baltic Sea: after the round goby invasion, flounder and turbot (Psetta maxima) juveniles were found to shift diets, resulting in an increased diet overlap with other species, and a lower feeding success, which together may have affected recruitment success of the fish (Ustups et al. 2015). Our analysis revealed potentially major overlap (up to 70\%) between the major competitor for food, the flounder, and the round goby distribution, which supports the above. Also, depth distribution of the round goby overlaps with small native gobies $\mathrm{Po}$ matoschistus spp., which predominantly inhabit shallow coastal areas, and the available evidence suggests that these small native gobies are negatively affected by round goby (Hempel et al. 2016). This effect may further cascade in the foodweb and affect recruitment abundance of a very valuable coastal commercial species-pikeperch (Zander lucioperca), for which larvae and early juveniles of Pomatoschistus spp. serve as the primary prey for early juveniles (MüllerKarulis et al. 2013). Although there is evidence that 
juvenile pikeperch can prey on the round goby (Hempel et al. 2016), the net effect of the round goby on the early juvenile stages of pikeperch is likely reduction of its primary food resource.

In addition to fish, round goby competes for the same prey with fish-eating birds. Dramatic decline in blue mussel availability and changed size structure at depths $<20 \mathrm{~m}$, associated with round goby distribution during the warm season (present study) and directly caused by round goby predation, induced a dietary shift in wintering long-tailed duck (Clangula hyemalis) towards fish prey in a coastal rocky habitat in the southern Baltic Sea. Such a shift has led to a reduction in carrying capacity of the bird in the study area, and shows that coastal habitats with low blue mussel biomass become less attractive wintering sites for seabirds (Skabeikis et al. 2019).

The ecological implications of biomass movement: round goby as prey

Introduction of non-native species can also be beneficial for some species in the invaded ecosystems. Although the individual/population level beneficial effects of the introduction of round goby on predatory fish still needs to be resolved within the Baltic Sea, round goby now serve as an important prey for both piscivorous fish and fish-eating birds (Stapanian et al. 2011; Crane et al. 2015; Hempel et al. 2016). Some fish-eating birds can switch to the round goby (Bzoma and Meissner, 2005), displaying increased consumption rates (Johnson et al. 2005) and indirect evidence of increases in population size; e.g. that grey heron (Ardea cinerea) population has increased in the southern Baltic Sea because of the rapid expansion of the round goby (Jakubas 2004). Our study evidenced that the distribution area of the round goby only moderately overlaps with that of one of the most abundant coastal predatory fishes perch), but this overlap undoubtedly offers a new (potentially) nutritionally profitable prey resource for the coastal piscivorous species (Brauer et al. 2020). This also adds to Liversage et al. (2017), who found that round goby densities do not significantly affect perch feeding, which is most likely affected by other environmental factors. The predominantly shallowwater occurrence of round goby, as evidenced in our study, may result in predation release of juveniles of commercial fish species from fish-eating birds
(Johnson et al. 2005). The main top predatory fish in the Baltic, cod (Gadus morhua) traditionally preys mainly on clupeids, but may shift to include substantial shares of round goby where these are abundant in coastal areas (Almqvist et al. 2010; Funk et al. 2020). In addition, from 2007 onwards, round goby has occurred in cod stomachs (Huwer et al. 2014), suggesting that they act as prey also for cod foraging on deeper waters.

Grey seal (Halichoerus grypus), and also to some extent harbour seal (Phoca vitulina), likewise consume round goby in the southern and southwestern Baltic Sea. While the share of round goby in harbour seal diet in 2001-2005 and 2013 was negligible (1\%), round goby constituted $17 \%$ of the grey seal diet in 2012-2013 (Scharff-Olsen et al. 2019). More recently (2017), round goby was the fish species with the highest occurrence in scats from a haul-out site by Rødsand (where round goby were first observed in 2011; Azour et al. 2015), occurring in 45 to $62 \%$ of the scats sampled in spring, summer and autumn in 2017 (no samplings in winter) (Kroner unpubl. data). Thus, locally, round goby can be an essential component of grey seal diets. As seals require food during the whole year, the seal-round goby interaction likely takes place both in shallower coastal areas as well as offshore and our round goby seasonal occurrence data is of high value for seal ecologists to interpret seal feeding ecology.

\section{Limitations of the research}

All available data on the round goby catches were compiled to provide a pan-Baltic perspective. Therefore, sampling techniques and applied fishing gears differ between seasons, years, and areas. It should be acknowledged that data obtained from some gear types may not be fully representative of the round goby distribution. For example, shallow-water and hard-bottom habitats can be underrepresented in the data from active gears, e.g. bottom trawls (Smoliński and Radtke 2017). On the contrary, some of the passive gears (e.g. gillnets) are not used in the deeper areas. However, applied standardization of Catch Per Unit Effort and mixed-effects modeling allowed for the partial control of these confounding effects of varying sampling techniques in the estimation of depth distribution and thermal preference of round goby. 
Lack of balance in the spatial and temporal coverage of the data should be considered when interpreting the results. We utilized only data from scientific surveys, but possible integration of the data from the commercial and recreational catches could be helpful to potentially improve the spatial and temporal resolution of future analyses (Støttrup et al. 2018).

Implications on future research, monitoring and assessment

As round goby occurrence and abundance data will continue to originate from various sources (there is no commonly agreed round goby monitoring protocols in the Baltic Sea), results of the current study provide the general background for interpretation of the locally collected seasonal data (e.g. those following the HELCOM coastal fish sampling guidelines). One of the immediate tasks should be estimation of the round goby abundance and density in different areas of the Baltic Sea by depth strata, to be further used not only for impact assessment and reporting purposes for the Descriptor 2 (non-indigenous species) of the European Union's Marine Strategy Framework Directive, but also future predictions, and to support developing mitigation measures.

Our results show pronounced seasonal migration of the round goby from the very shallow coastal areas to the deep offshore regions and vice versa, similar to findings in North American freshwater environments (Andres et al. 2020, Pennuto et al. 2021). Both the spatial distribution (Kotta et al. 2016) as well as biomass of the round goby has increased over time in the Baltic Sea (up to 350 individuals $/ 100 \mathrm{~m}^{2}$; Sapota and Skora 2004; Puntila et al. 2018), which has resulted in increased translocation of organic matter and energy to deeper offshore regions over time. Further investigations should be aimed at quantifying the food web consequences and coupling effects between different habitats associated with seasonal migrations of the round goby, both in terms of the species as a competitor, predator and prey.

Acknowledgements This work was supported by the J.P.A. Espersen and Mrs Dagny Espersen Foundation (Grant number 16/12677) and the Joint Baltic Sea Research and Development Programme (BONUS) project 'Taking stock of Baltic Sea food webs: synthesis for sustainable use of ecosystem goods and services', XWEBS, which were supported by BONUS (Art 185), funded jointly by the European Union, the Estonian
Research Council, the Innovation Fund Denmark, the Forschungszentrum Jülich Beteiligungsgesellschaft $\mathrm{mbH}$ (Germany) and Academy of Finland. Some of the data collection was financed by the BONUS INSPIRE project supported by the Joint Baltic Sea Research and Development Programme BONUS (Art. 185), funded jointly by the EU and the National Research funding Institutions in the seven EU Member States around the Baltic Sea (Denmark, Estonia, Finland, Germany, Latvia, Poland and Sweden). An early draft of this manuscript benefited from constructive comments of two anonymous reviewers.

Funding This work was supported by the J.P.A. Espersen and Mrs Dagny Espersen Foundation (Grant number 16/12677) and the Joint Baltic Sea Research and Development Programme (BONUS) project 'Taking stock of Baltic Sea food webs: synthesis for sustainable use of ecosystem goods and services', XWEBS, which were supported by BONUS (Art 185), funded jointly by the European Union, the Estonian Research Council, the Innovation Fund Denmark, the Forschungszentrum Jülich Beteiligungsgesellschaft $\mathrm{mbH}$ (Germany) and Academy of Finland. Some of the data collection was financed by the BONUS INSPIRE project supported by the Joint Baltic Sea Research and Development Programme BONUS (Art. 185), funded jointly by the EU and the National Research funding Institutions in the seven EU Member States around the Baltic Sea (Denmark, Estonia, Finland, Germany, Latvia, Poland and Sweden).

\section{Declarations}

Conflict of interest There is no conflicts of interest.

Consent for publication All authors have given approval for publication.

Open Access This article is licensed under a Creative Commons Attribution 4.0 International License, which permits use, sharing, adaptation, distribution and reproduction in any medium or format, as long as you give appropriate credit to the original author(s) and the source, provide a link to the Creative Commons licence, and indicate if changes were made. The images or other third party material in this article are included in the article's Creative Commons licence, unless indicated otherwise in a credit line to the material. If material is not included in the article's Creative Commons licence and your intended use is not permitted by statutory regulation or exceeds the permitted use, you will need to obtain permission directly from the copyright holder. To view a copy of this licence, visit http://creativecommons.org/licenses/by/4.0/.

\section{References}

Almqvist G, Strandmark AK, Appelberg M (2010) Has the invasive round goby caused new links in Baltic food webs? Environ Biol Fishes 89:79-93. https://doi.org/10.1007/ s10641-010-9692-Z 
Amante C, Eakins BW (2003) ETOPO1 1 arc-minute global relief model: procedures, data sources and analysis. NOAA Technical Memorandum NESDIS NGDC-24

Andres KJ, Sethi SA, Duskey E et al (2020) Seasonal habitat use indicates that depth may mediate the potential for invasive round goby impacts in inland lakes. Freshw Biol 65:1337-1347. https://doi.org/10.1111/fwb.13502

Azour F, van Deurs M, Behrens J, Carl H, Hüssy K, Greisen K, Ebert R, Møller PR (2015) Invasion rate and population characteristics of the round goby Neogobius melanostomus: Effects of density and invasion history. Aquat Biol 24:41-52. https://doi.org/10.3354/ab00634

BACC (2015) Second Assessment of Climate Change for the Baltic Sea Basin. pp. 474

Balshine S, Verma A, Chant V, Theysmeyer T (2005) Competitive Interactions between Round Gobies and Logperch. J Great Lakes Res 31:68-77. https://doi.org/10.1016/ S0380-1330(05)70238-0

Bauer S, Hoye BJ (2014) Migratory animals couple biodiversity and ecosystem functioning worldwide. Science 344:1242552. https://doi.org/10.1126/science.1242552

Bazazi S, Romanczuk P, Thomas S, Schimansky-Geier L, Hale JJ, Miller GA, Sword GA, Simpson SJ, Couzin ID (2011) Nutritional state and collective motion: from individuals to mass migration. Proc R Soc B 278:356-363. https://doi. org/10.1098/rspb.2010.1447

Bergstrom MA, Mensinger AF (2009) Interspecific resource competition between the invasive round goby and three native species: logperch, slimy sculpin, and spoonhead sculpin. Trans Am Fish Soc 138:1009-1017. https://doi. org/10.1577/T08-095.1

Brauer M, Behrens JW, Christoffersen M, Hyldig G, Jacobsen C, Björnsdottir KH, van Deurs M (2020) Seasonal patterns in round goby (Neogobius melanostromus) catch rates, catch composition, and dietary quality. Fish Res 222:105412. https://doi.org/10.1016/j.fishres.2019.105412

Brodersen J, Nilssson PA, Hansson L-A, Skov C, Brönmarck C (2008) Condition-dependent individual decision-making determines cyprinid partial migration. Ecology 89:1195-1200. https://doi.org/10.1890/07-1318.1

Brönmark C, Skov C, Brodersen J, Nilsson PA, Hansson L-A (2008) Seasonal migration determined by a trade-off between predator avoidance and growth. PLoS ONE 3(4):e1957. https://doi.org/10.1371/journal.pone.0001957

Burnham K, Anderson DR (1998) Model selection and inference: a practical information-theoretical approach. Springer-Verlag, New York

Bzoma S, Meissner W (2005) Some results of long-term counts of waterbirds wintering in the western part of the Gulf of Gdańsk (Poland), with special emphasis on the increase in the number of cormorants (Phalacrocorax carbo). Acta Zool Litu 15:105-108. https://doi.org/10.1080/13921657. 2005.10512383

Chowdhury GW, Zieritz A, Aldridge DC (2016) Ecosystem engineering by mussels supports biodiversity and water clarity in a heavily polluted lake in Dhaka, Bangladesh. Fresh Sci 35:188-199. https://doi.org/10.1086/684169

Christensen EAF, Norin T, Tabak I, van Deurs M, Behrens JW (2021) Effects of temperature on physiological performance and behavioral thermoregulation in an invasive fish, the round goby. J Exp Biol. https://doi.org/10.1242/jeb. 237669

Christoffersen M, Svendsen JC, Behrens JW, Jepsen N, van Deurs M (2019) Using acoustic telemetry and snorkel surveys to study diel activity and seasonal migration of round goby (Neogobius melanostomus) in an estuary of the Western Baltic Sea. Fish Manag Ecol 26:172-182. https:// doi.org/10.1111/fme.12336

Crane DP, Einhouse DW (2015) Changes in growth and diet of smallmouth bass following invasion of Lake Erie by the round goby. J Great Lakes Res 42:405-412. https://doi.org/ 10.1016/j.jglr.2015.12.005

Deegan LA (1993) Nutrient and energy transport between estuaries and coastal marine ecosystems by fish migration. Can J Fish Aquat Sci 50:74-79. https://doi.org/10.1139/ f93-009

Dingle H, Drake AV (2007) What is migration? Bioscience 57:113-121. https://doi.org/10.1641/B570206

Donadi S, Van der Heide T, Piersma T, Van der Zee EM, Weerman EJ, Van de Koppel J et al (2015) Multi-scale habitat modification by coexisting ecosystem engineers drives spatial separation of macrobenthic functional groups. Oikos 124:1502-1510. https://doi.org/10.1111/oik. 02100

Dumont HJ (1998) The Caspian lake: history, biota, structure, and function. Limnol Oceanogr 43:44-52

French JRP, Jude DJ (2001) Diets and diet overlap of nonindigenous gobies and small benthic native fishes co-inhabiting the St. Clair River. Michigan J Great Lakes Res 27:300-311

Funk S, Frelat R, Möllmann C, Temming A, Krumme U (2020) The forgotten feeding ground: patterns in seasonal and depth-specific food intake of adult cod Gadus morhua in the western Baltic Sea. J Fish Biol. https://doi.org/10.1111/ jfb. 14615

Grygiel W, Trella K, Grelowski A (2004) Variation in the occurrence of visiting, non-numerous, and alien fish species in the autumn-winter seasons of 1976-2004 in the southern Baltic Sea. Poster No. 69/PH02-Alien Fish Species Symposium (6-10.09.2004, Tallinn); [in: XI European Congress of Ichthyology, Abstract volume], p. 179

Hempel M, Neukamm R, Thiel R (2016) Effects of introduced round goby (Neogobius melanostomus) on diet composition and growth of zander (Sander lucioperca), a main predator in European brackish waters. Aquat Invasions 11:167-178. https://doi.org/10.3391/ai.2016.11.2.06

Herborg LM, Rushton SP, Clare AS, Bentley MG (2003) Spread of the Chinese mitten crab (Eriocheir sinensis $\mathrm{H}$. Milne Edwards) in Continental Europe: analysis of a historical data set. Hydrobiologia 503:21-28

Huwer B, Neuenfeldt S, Rindorf A, Andreasen H, Levinsky SE, Storr-Paulsen M et al (2014) Study on stomach content of fish to support the assessment of good environmental status of marine food webs and the prediction of MSY after stock restoration (No. MARE/2012/02). European Commission

Jakubas D (2004) The response of the grey heron to a rapid increase of the round goby. Waterbirds 27:304-307. https://doi.org/10.1675/1524-4695(2004)027[0304: TROTGH]2.0.CO;2 
Johnson TB, Bunnell DB, Knight CT (2005) A potential new energy pathway in Central Lake Erie: the round goby connection. J Great Lakes Res 31:238-251. https://doi.org/ 10.1016/S0380-1330(05)70317-8

Kanciruk P, Herrnkind W (1978) Mass migration of spiny lobster, panulirus argus (crustacea: palinuridae): behavior and environmental correlates. Bull Mar Sci 28:601-623. https://doi.org/10.1007/978-3-662-11147-5_43

Karlson AML, Almqvist G, Skóra KE, Appelberg M (2007) Indications of competition between non-indigenous round goby and native flounder in the Baltic Sea. ICES J Mar Sci 64:479-486. https://doi.org/10.1093/icesjms/fs1049

Kornis MS, Mercado-Silva N, Vander Zanden MJ (2012) Twenty years of invasion: a review of round goby Neogobius melanostomus biology, spread and ecological implications. J Fish Biol 80:235-285. https://doi.org/10. 1111/j.1095-8649.2011.03157.x

Kotta J, Nurkse K, Puntila R, Ojaveer H (2016) Shipping and natural environmental conditions determine the distribution of the invasive non-indigenous round goby Neogobius melanostomus in a regional sea. Estuar Coast Shelf Sci 169:15-24. https://doi.org/10.1016/j.ecss.2015.11.029

Lederer A, Janssen J, Reed T, Wolf A (2008) Impacts of the introduced Round Goby (Apollonia melanostoma) on dreissenids (Dreissena polymorpha and Dreissena bugensis) and on macroinvertebrate community between 2003 and 2006 in the littoral zone of Green Bay, Lake Michigan. J Great Lakes Res 34:690-697. https://doi.org/10.1016/ S0380-1330(08)71611-3

Leggett WC (1977) The ecology of fish migrations. Ann Rev Ecol Syst 8:285-308. https://doi.org/10.1146/annurev.es. 08.110177 .001441

Liversage K, Nurkse K, Kotta J, Järv L (2017) Environmental heterogeneity associated with European perch (Perca fluviatilis) predation on invasive round goby (Neogobius melanostomus). Mar Environ Res 132:132-139. https:// doi.org/10.1016/j.marenvres.2017.10.017

Lucas MC, Baras E (2001) Migration of freshwater fishes. Blackwell Science, Oxford. pp 420

Marczak LB, Thompson RM, Richardson JS (2007) Metaanalysis: trophic level, habitat, and productivity shape the food web effects of resource subsidies. Ecology 88:140-148. https://doi.org/10.1890/00129658(2007)88[140:MTLHAP]2.0.CO;2

Müller-Karulis B, Arula T, Balode M, Laur K, Ojaveer E (2013) Challenges and opportunities of local fisheries management: pikeperch, Sander lucioperca (Actinopterygii: Perciformes: Percidae), in Pärnu Bay, northern Gulf of Riga. Baltic Sea Acta Ichthyol Pisca 43:151-161. https://doi.org/ 10.3750/AIP2013.43.2.08

Nichol DG, Somerton DA (2015) Seasonal migrations of morphometrically mature male snow crab (Chionoecetes opilio) in the eastern Bering Sea in relation to mating dynamics. Fish. Bull. 113:313-326. https://doi.org/10. 7755/FB.113.3.7

Nurkse K, Kotta J, Orav-Kotta H, Ojaveer H (2016) A successful non-native predator, round goby, in the Baltic Sea: generalist feeding strategy, diverse diet and high prey consumption. Hydrobiologia 777:271-281. https://doi.org/ 10.1007/s10750-016-2795-6
O'Driscoll RL (2004) Estimating uncertainty with acoustic surveys of spawning hoki (Macruronus novaezelandiae) in Cook Strait, New Zealand. ICES J Mar Sci 61:84-97. https://doi.org/10.1016/J.ICESJMS.2003.09.003

Ojaveer H, Galil BS, Lehtiniemi M, Christoffersen M, Clink S, Florin A-B et al (2015) Twenty five years of invasion: management of the round goby Neogobius melanostomus in the Baltic Sea. Man Biol Inv 6:329-339. https://doi.org/ 10.3391/mbi.2015.6.4.02

Olenin S (2002) Black Sea-Baltic Sea invasion corridors. CIESM Workshop Monographs 20:29-33

Pante E, Simon-Bouhet B, Irisson J-O (2017) Marmap: import, plot and analyze bathymetric and topographic data. Available at: https://github.com/ericpante/marmap.

Pennuto CM, Mehler K, Weidel B, Lantry BF, Bruestle E (2021) Dynamics of the seasonal migration of Round Goby (Neogobius melanostomus, Pallas 1814) and implications for the Lake Ontario food web. Ecol Freshw Fish 30:151-161. https://doi.org/10.1111/eff.12568

Petersen JK, Saurel C, Nielsen P, Timmermann K (2016) The use of shellfish for eutrophication control. Aqua International 24:857-878. https://doi.org/10.1007/s10499-0159953-0

Pinheiro J, Bates D, DebRoy S, Sarkar D, R Core Team (2016) 'nlme: Linear and Nonlinear Mixed Effects Models.' Available at: http://cran.r-project.org/package=nlme.

Poos M, Dextrase AJ, Schwalb AN, Ackerman JD (2010) Secondary invasion of the round goby into high diversity Great Lakes tributaries and species at risk hotspots: potential new concerns for endangered freshwater species. Biol Inv 12:1269-1284. https://doi.org/10.1007/s10530-009-9545$\mathrm{x}$

Puntila, R, Strake S, Florin A-B, Naddafi R, Lehtiniemi M, Behrens J, Kotta J, Oesterwind D, Putnis I, Smolinski S, Wozniczka A, Ojaveer H, Lozys L, Uspenskiy A, Yurtseva A (2018) Abundance and distribution of Round goby (Neogobius melanostomus). HELCOM Baltic Sea Environment Fact Sheet 2018

Quinn TP, Dittman AH (1990) Pacific salmon migrations and homing: mechanisms and adaptive significance. Trends Ecol Evol 5:174-177. https://doi.org/10.1016/01695347(90)90205-R

R Core Team (2016) 'R: A language and environment for statistical computing'. Vienna, Austria: R Foundation for Statistical Computing. Available at: https://www.r-project. org/.

Reynolds WW, Casterlin ME (1979) Behavioral thermoregulation and the "final preferendum" paradigm. Am Zool 19:211-224. https://doi.org/10.1093/icb/19.1.211

Sapota MR (2004) The round goby (Neogobius melanostomus) in the Gulf of Gdańsk- a species introduction into the Baltic Sea. Hydrobiologia 514:219-224. https://doi.org/10. 1023/B:hydr.0000018221.28439.ae

Sapota MR, Skora KE (2005) Spread of alien (non-indigenous) fish species Neogobius melanostomus in the Gulf of Gdansk (south Baltic). Biol Inv 7:157-164. https://doi.org/ 10.1007/s10530-004-9035-0

Scharff-Olsen CH, Galatius A, Teilmann J, Dietz R, May Andersen SM, Jarnit S, Kroner A-M, Botnen AB, Lundström K, Møller PR, Olsen MT (2019) Diet of seals in the Baltic Sea region: a synthesis of published and new data 
from 1968 to 2013. ICES J Mar Sci 76:284-297. https:// doi.org/10.1093/icesjms/fsy159

Schrandt M, Stone L, Klimek B, Mäkelin S, Heck Jr K, Mattila J, Herlevi H (2016) A laboratory study of potential effects of the invasive round goby on nearshore fauna of the Baltic Sea. Aquatic Invasions 11: 327-335. https://doi.org/10. 3391/ai.2016.11.3.10

Schwartzbach A, Behrens JW, Svendsen JC, Nielsen P, van Deurs M (2019) Size-dependent predation of round goby Neogobius melanostomus on blue mussels Mytilus edulis. Fish Manag Ecol 27:215-218. https://doi.org/10.1111/fme. 12400

Sigler MF, Csepp DJ (2007) Seasonal abundance of two important forage species in the North Pacific Ocean, Pacific herring and walleye Pollock. Fish Res 83:319-331. https:// doi.org/10.1016/j.fishres.2006.10.007

Skabeikis A, Lesutiené J (2015) Feeding activity and diet composition of round goby (Neogobius melanostomus, Pallas 1814) in the coastal waters of SE Baltic Sea. Oceano Hydrobiol Studies 44:508-519. https://doi.org/10.1515/ ohs-2015-0048

Skabeikis A, Morkūnė R, Bacevičius E, Lesutienè J, Morkūnas J, Poškienè A, Šiaulys A (2019) Effect of round goby (Neogobius melanostomus) invasion on blue mussel (Mytilus edulis trossulus) population and winter diet of the long-tailed duck (Clangula hyemalis). Biol Invasions 21:911-923. https://doi.org/10.1007/s10530-018-1869-y

Smoliński S, Radtke K (2017) Spatial prediction of demersal fish diversity in the Baltic Sea: comparison of machine learning and regression-based techniques. ICES J Mar Sci 74:102-111. https://doi.org/10.1093/icesjms/fsw136

Stapanian MA, Edwards WH, Witzel LD (2011) Recent changes in burbot growth in Lake Erie. J Appl Ichthyol 27(Suppl. 1):57-64. https://doi.org/10.1111/j.1439-0426.2011. 01845.x

Støttrup JG, Kokkalis A, Brown EJ, Olsen J, Andersen KS, Pedersen EM (2018) Harvesting geo-spatial data on coastal fish assemblages through coordinated citizen science. Fish Res 208:86-96. https://doi.org/10.1016/j.fishres.2018.07. 015
Sunday JM, Bates AE, Kearney MR, Colwell RK, Dulvy NK, Longino JT et al (2014) Thermal-safety margins and the necessity of thermoregulatory behavior across latitude and elevation. Proc Natl Acad Sci 111:5610-5615. https://doi. org/10.1073/pnas.1316145111

Tamburello N, Côté IM (2015) Movement ecology of IndoPacific lionfish on Caribbean coral reefs and its implications for invasion dynamics. Biol Invasions 17:1639-1653. https://doi.org/10.1007/s10530-014-0822-y

Ustups D, Bergström U, Florin A-B, Krūze Ē, Zilniece D, Elferts D, Knospina E, Uzars D (2015) Diet overlap between juvenile flatfish and the invasive round goby in the central Baltic Sea. J Sea Res 106:121-129. https://doi.org/10. 1016/j.seares.2015.06.021

van Deurs M, Persson A, Lindegren M, Jacobsen C, Neuenfeldt S, Jørgensen C, Nilsson A (2016) Marine ecosystem connectivity mediated by migrant-resident interactions and the concomitant cross-system flux of lipids. Ecol Evol 6:4076-4087. https://doi.org/10.1002/ece3.2167

Varpe $\varnothing$, Fiksen $\varnothing$, Slotte A (2005) Meta-ecosystems and biological energy transport from ocean to coast: the ecological importance of herring migration. Oecologia 146:443-451. https://doi.org/10.1007/s00442-005-0219-9

Walsh MG, Dittman DE, O'Gorman R (2007) Occurence and food habits of the round goby in the profundal zone of Southwestern Lake Ontario. Internat Assoc Great Lakes Res 33:83-92. https://doi.org/10.3394/03801330(2007)33[83:OAFHOT]2.0.CO;2

Wiegleb J, Kotterba P, Hammer C, Oesterwind D (2019) Predation of the round goby (Neogobius melanostomus, Pallas, 1814) on Atlantic herring eggs in the Western Baltic Sea. Mar Biol Res 14:989-1003. https://doi.org/10.1080/ 17451000.2019.1577977

Zuur A, Ieno EN, Walker N, Saveliev AA, Smith GM (2009) Mixed effects models and extensions in ecology with R, Statistics for Biology and Health. Springer, New York

Publisher's Note Springer Nature remains neutral with regard to jurisdictional claims in published maps and institutional affiliations. 